
\title{
25 Research Square \\ Meridional Changes in The South Atlantic Subtropical Gyre During Heinrich Stadials
}

\author{
Tainã Pinho ( $\nabla$ taina.pinho@usp.br) \\ Universidade de São Paulo \\ Cristiano Chiessi \\ Universidade de São Paulo \\ Rodrigo Portilho-Ramos \\ University of Bremen \\ Marília Campos \\ Universidade de São Paulo \\ Stefano Crivellari \\ Universidade de São Paulo \\ Rodrigo Nascimento \\ Fluminense Federal University \\ Ana Albuquerque \\ Fluminense Federal University \\ André Bahr \\ Heidelberg University \\ Stefan Mulitza \\ University of Bremen
}

\section{Research Article}

Keywords: planktonic foraminiferal, Globorotalia truncatulinodes, Paleoceanographic, climate system

Posted Date: December 7th, 2020

DOI: https://doi.org/10.21203/rs.3.rs-115324/v1

License: (c) (i) This work is licensed under a Creative Commons Attribution 4.0 International License.

Read Full License 


\section{Abstract}

Subtropical ocean gyres play a key role in modulating the global climate system redistributing energy between low and high latitudes. A poleward displacement of the subtropical gyres has been observed over the last decades, but the lack of long-term monitoring data hinders an in-depth understanding of their dynamics. Paleoceanographic records offer the opportunity to identify meridional changes in the subtropical gyres and investigate their consequences to the climate system. Here we use the abundance of planktonic foraminiferal species Globorotalia truncatulinodes from a sediment core collected at the northernmost boundary of the South Atlantic Subtropical Gyre (SASG) together with a previously published record of the same species from the southernmost boundary of the SASG to reconstruct meridional fluctuations of the SASG over last ca. $70 \mathrm{kyr}$. Our findings indicate southward displacements of the SASG during Heinrich Stadials (HS) 6-4 and HS1, and a contraction of the SASG during HS3 and HS2. During HS6-4 and HS1, the SASG southward displacements likely boosted the transfer of heat to the Southern Ocean, ultimately strengthening deep-water upwelling and $\mathrm{CO}_{2}$ release to the atmosphere. We hypothesize that the ongoing SASG poleward displacement may further increase oceanic $\mathrm{CO}_{2}$ release.

\section{Introduction}

Subtropical gyres are large systems of anticyclonic upper ocean circulation driven by wind stress curl ${ }^{1,2}$, characterized as enormous reservoirs of heat and salt ${ }^{3}$. They are major pathways of energy redistribution between low and high latitudes with a pivotal role on the global climatic system ${ }^{4}$. As part of the subtropical gyres, western boundaries currents (e.g., Brazil Current (BC) and Gulf Stream) transport warm and salty tropical waters towards the poles, and eastern boundaries currents (e.g., Benguela and Canary Currents) transport cold and fresh waters towards the equator. At their midlatitude boundaries, subtropical gyres are limited by the Subtropical Fronts (STF).

Observational and model studies suggest a poleward migration of the subtropical gyres in the order of $0.1^{\circ}$ per decade, driven by a systematic poleward displacement of the extratropical atmospheric circulation ${ }^{5}$. Changes in the geometry, strength and extension of the subtropical gyres may disturb the meridional heat transport with drastic consequences to marine ecosystems and the global climate system $^{5,6}$. An increased heat transport along the western boundary currents has been registered during the last decades (e.g., ${ }^{7,8}$ ). In the western South Atlantic, warming of the $\mathrm{BC}$ has been claimed to cause a severe dwindling of commercial fish stocks ${ }^{9}$. Even total marine productivity is projected to decline due to the expansion of the "ocean deserts", i.e., the oligotrophic subtropical gyres ${ }^{10,11}$. Yet, it still not clear if modern changes in the subtropical gyres are promoted by anthropogenic activities or natural climate variability, mostly because of the relatively short instrumental observations. Paleoceanographic records offer a great opportunity to identify long-term changes in the subtropical gyres under different climatic conditions. This type of information is crucial to validate coupled climate models and improve our understanding of the potential anthropogenic role on the ongoing poleward shift of the subtropical gyres ${ }^{5}$. 
Paleoceanographic studies provide evidences for latitudinal shifts of the Subtropical and the Subantarctic Fronts on orbital and millennial timescales (e.g., $\left.{ }^{12-16}\right)$. In the Atlantic sector of the Southern Ocean, the northward the northward displacement of the Subtropical and the Subantarctic Fronts during full glacials hampered the exchange of heat and salt between the Atlantic and the Indian Oceans through the Agulhas Leakage ${ }^{12,16}$. In contrast, these fronts shifted southwards during millennial-scale climate events, the so-called Heinrich Stadials (HS) ${ }^{13,14}$. Despite the knowledge about the Subtropical and Subantarctic Fronts, the past behavior of the South Atlantic Subtropical Gyre (SASG) and its consequences for the climate system remain unknown.

Globorotalia truncatulinoides is a deep-dwelling planktonic foraminiferal species that calcifies its shells within the permanent thermocline ${ }^{17,18,19}$. This species presents an one-year reproductive cycle with extensive vertical migration in the water column that is highly dependent on the stratification of the upper ocean $^{20,21}$. Therefore, $G$. truncatulinoides increases (decreases) in abundance when the thermocline is deeper (shallower) ${ }^{19,21}$. The coiling direction of G. truncatulinoides has been commonly used to reconstruct the upper water column stratification ${ }^{21,22}$, although surface sediments from the Atlantic Ocean reveal that the distribution of both sinistral and dextral morphotypes of $G$. truncatulinoides are closely related to the subtropical gyres ${ }^{23}$, showing high abundance inside the gyres, where the thermocline is deeper, and being virtually absent to the north and south of the gyres, where the thermocline is shallower (Fig. 1a-c). Thus, the abundance of $G$. truncatulinoides in adequately located marine sediment cores is an excellent proxy to track meridional changes in the subtropical gyres.

Here we compare the relative abundance of $G$. truncatulinoides from two sediment cores located on opposite sides of the modern SASG (Fig. 1), which are key locations to track past meridional displacements of the SASG ${ }^{5}$. We provide a new record of $G$. truncatulinoides abundance from core M12595-3 $\left(10.94^{\circ} \mathrm{S}, 36.20^{\circ} \mathrm{W}, 1897 \mathrm{~m}\right.$ water depth) raised from the continental slope of the western tropical South Atlantic at the northern boundary of the SASG (nSASG) that covers the last ca. 70 kyr (Fig. 1a, d). We compare this record with the previously published abundance of $G$. truncatulinoides from core MD07$3076 \mathrm{Q}\left(44.92^{\circ} \mathrm{S}, 14.13^{\circ} \mathrm{W}, 3770 \mathrm{~m} \text { water depth }\right)^{24}$, collected at the southern boundary of the SASG (SSASG) (Fig. 1a, d). High-resolution data from both cores allow investigating millennial-scale changes in the SASG. The position of both cores has been strategically selected so that a meridional displacement of the SASG should cause antiphase excursions in G. truncatulinoides abundance in both cores. On the other hand, a contraction (expansion) of the SASG would cause a decrease (increase) in the abundance of $G$. truncatulinoides in both cores or a decrease (increase) in the abundance in one of the cores and no change in the other.

\section{Materials And Methods}

Piston core M125-95-3 was collected from the continental slope of the western tropical South Atlantic during RV Meteor cruise M125 (Fig. 1a, d) ${ }^{30}$. We focus on the uppermost $7.4 \mathrm{~m}$ of the core which spans the last ca. $70 \mathrm{kyr}$ covering all HS of the last glacial and deglacial periods (the age model was previously 
published $\mathrm{in}^{31}$ ). The age model is based on nine calibrated planktonic foraminifera accelerator mass spectrometry radiocarbon ages. For the portion of the core beyond the radiocarbon range, Uvigerina spp. stable oxygen isotopic $\left(\delta^{18} 0\right)$ tie-points were tuned to a benthic $\delta^{18} 0$ reference curve from ${ }^{32}$. The age modeling algorithm BACON v. 2.2 $2^{33}$ was used within the software PaleoDataView v. 0.8.3.4 ${ }^{34}$ to produce the age model. The relative abundance of planktonic foraminifera $G$. truncatulinoides were counted in the $>150 \mu \mathrm{m}$ size fraction and its relative abundance was quantified from splits containing more than 300 specimens. We distinguished the sinistral and dextral morphotypes specimens of $G$. truncatulinoides, however, in the present study we choose to pool them together due to the very low abundance of the sinistral morphotype.

Modern distribution of Globorotalia truncatulinoides. The modern spatial distribution of planktonic foraminifera Globorotalia truncatulinoides in Atlantic Ocean sediments was extracted from (ref. 23). The comparison of its spatial distribution with upper water column structure, circulation and physicochemical properties suggests that $G$. truncatulinoides track the meridional position of the South Atlantic Subtropical Gyre ${ }^{19,21,23}$. Globorotalia truncatulinoides shows high abundance inside the gyre where the thermocline is deep, and is virtually absent to the north and south of the gyre where the thermocline is shallow. In (ref. 23), foraminifera were picked from the $>150 \mu \mathrm{m}$ size fraction of sample splits containing around 300 specimens $^{23}$, the same method applied here. Further details on the ages of modern surface sediments can be found in (ref. 23). Modern foraminiferal data used here are available from the World Data Center PANGAEA (https://doi.pangaea.de/10.1594/PANGAEA.841194).

Marine sediment core. Marine sediment core M125-95-3 $\left(10.94^{\circ} \mathrm{S}, 36.20^{\circ} \mathrm{W}, 1897 \mathrm{~m}\right.$ water depth, $1040 \mathrm{~cm}$ long) was collected from the continental slope of the western tropical South Atlantic during RV Meteor cruise $\mathrm{M} 125^{30}$. Here we examined the upper $740 \mathrm{~cm}$ of the core that span the last ca. $70 \mathrm{kyr}$ and cover all Heinrich Stadials (HS) of the last glacial and deglacial periods. This section was sampled with $10 \mathrm{~cm}^{3}$ syringes. Samples were wet-sieved, oven-dried at $50^{\circ} \mathrm{C}$ and the size fraction higher than $125 \mu \mathrm{m}$ was stored in glass vials. Faunal analyses were conducted every $10 \mathrm{~cm}$ for the whole investigated section but sampling space was decreased in the neighborhood and within every HS. 144 samples were analyzed.

Identification of planktonic foraminifera. The wet-sieved and oven-dried $>125 \mathrm{~mm}$ fraction was drysieved in a $150 \mu \mathrm{m}$ sieve, and the $>150 \mathrm{~mm}$ fraction was used for the determination of the relative abundances of the species that were quantified from splits containing more than 300 specimens. Taxonomy was based on (ref. 67) and (ref. 68). Here we present the abundance of planktonic foraminifera species Globorotalia truncatulinoides (both dextral and sinistral morphotypes). Since sediment core M125-95-3 was collected well above the glacial lysocline depth ${ }^{69}$, we considered the effect of dissolution in our planktonic foraminiferal faunal composition to be negligible. The planktonic foraminifera G. truncatulinoides record from sediment core MD07-3076Q was previously published by (ref. 24).

Age model. The age model of sediment core M125-95-3 was previously published by (ref. 31). It combines nine calibrated planktonic foraminifera accelerator mass spectrometry radiocarbon ages and 
tunning benthic foraminifera $\delta^{18} 0$ tie-points to a benthic $\delta^{18} 0$ reference curve from (ref. 32). The age modeling algorithm BACON v. $2.2^{33}$ was used within the software PaleoDataView v. $0.8 .3 .4^{34}$ for agedepth modeling.

\section{Results}

The relative abundance of $G$. truncatulinoides in core M125-95-3 ranges between 0 and $5.9 \%$, with mean value of $1.7 \%$ during the last glacial period and $0.8 \%$ during the Holocene (Fig. 2c). Millennial-scale negative excursions of up to $5.9 \%$ characterize the relative abundance record of $G$. truncatulinoides and coincide with all HS of the last glacial period.

\section{Discussion}

\section{Millennial-scale changes in the northern boundary of the South Atlantic Subtropical Gyre}

The decreases in the relative abundance of $G$. truncatulinoides occurred simultaneously with increases in precipitation over NE Brazil that were, in turn, associated to southward displacements in the Intertropical Convergence Zone (ITCZ) during HS (Fig. 2c-d) ${ }^{28,39}$. The meridional position of the ITCZ determines the location of the equatorial ascending branch of the Hadley Cells. The Hadley Cells from both hemispheres have an important role in the interhemispheric atmospheric heat transport ${ }^{40}$. Under a weak Atlantic

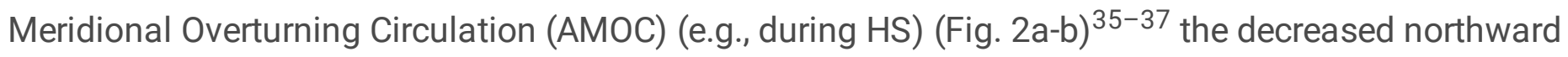
oceanic heat transport warmed the South Atlantic ${ }^{13,41}$. This resulted in a southward migration of the equatorial ascending branch of the Hadley Cells, partially compensating the decrease in northward oceanic heat transport via an increase in the northward atmospheric heat transport ${ }^{42,43}$.

Changes in the Hadley Cells directly affect the oceanic Subtropical Cells (STC) by changing the trade winds stress on the surface. Indeed, the wind-driven oceanic STC can be described as the upper ocean counter-part of the Hadley Cell ${ }^{44}$. Therefore, changes in the meridional position of the equatorial branch of the STC are linked to the ITCZ position via the Hadley Cell ${ }^{45}$. During HS, (ref. 43) described a southward shift of the ascending branch of the South Atlantic STC that followed the ITCZ ${ }^{43}$. The southward shift of the STC in the South Atlantic should lead to the southward displacement of the nSASG during HS. We suggest that southward migrations of the nSASG during HS increased the upper water column stratification (i.e., shallower thermocline) at our core site, decreasing the abundance of $G$. truncatulinoides (Figs. 2c, 3a). An increased stratification in the upper water column of the western tropical South Atlantic during HS has been confirmed by (ref. 46) and (ref. 47) (Fig. S1d), supporting our suggestion.

In line with our results, in the tropical North Atlantic at the southern boundary of the North Atlantic Subtropical Gyre (sNASG), increases in the abundance of G. truncatulinoides (Fig. S1e) ${ }^{27}$ during HS 
suggest southward migrations of the sNASG. This is supported by upper water column temperature and salinity data ${ }^{48}$, as well as model experiments ${ }^{49}$, suggesting a tight coupling between the ascending branches of both STC and subtropical gyres in the Atlantic during HS.

The suggested southward migrations of the NSASG during HS were also accompanied by decreases in the strength of the SE trade winds ${ }^{50}$, a consequence of the decreased meridional SST gradient in the South Atlantic ${ }^{13,41}$. The reduced strength of the SE trade winds was thus co-responsible for the increases in upper water column stratification in the western tropical South Atlantic. At our core site, however, the large amplitude decreases in the abundance of G. truncatulinoides (Figs. 2c, 3a) point to the occurrence of changes in upper water column structure. Such changes would be accomplished by the nSASG crossing southwards our core site (Fig. 1).

Moreover, our core site is located at the modern bifurcation of the South Equatorial Current (SEC) in the upper $100 \mathrm{~m}$ of the water column (Fig. 1d). Our suggestion of southward migrations of the nSASG to be dynamically linked to southward shifts of the ITCZ position during HS contrasts to the seasonal mode of changes in the SEC bifurcation (i.e., during austral summer, a southward migration of the ITCZ occurs simultaneously to a northward migration of the SEC bifurcation) ${ }^{51}$. Thus, our results highlight the need to consider the timescale while investigating the processes responsible for changes in western tropical South Atlantic upper water column stratification.

\section{Impacts of changes in the South Atlantic Subtropical Gyre}

The G. truncatulinoides abundance records from the nSASG (core M125-95-3) and the SSASG (core MD07-3076Q) reveal an antiphase pattern during HS6-4 and HS1 (Fig. 3a-b). Notably, in both G. truncatulinoides records, sinistral and dextral morphotypes were quantified together. While in the nSASG G. truncatulinoides abundance decrease during HS6-1 (Fig. 3a), in the SSASG G. truncatulinodes abundance increase during the HS6-4 and HS1 with no clear trend during HS3 and HS2 (Fig. 3b) ${ }^{24}$. The antiphase pattern suggests that the whole SASG was displaced southwards during HS6-4 and HS1. In contrast, the reduction in G. truncatulinoides in the nSASG together with constant values in the SSASG suggests a meridional contraction of the SASG during HS3 and HS2 (Fig. 3a-b).

The Southern Hemisphere westerly winds control the position of the STF in the South Atlantic (e.g., $\left.{ }^{56}\right)$. A southward displacement of the STF during HS has been suggested ${ }^{57}$. The concurrent HS increases in the abundance of $G$. truncatulinoides in the SSASG (Fig. 3b) and the decreases in dust flux around Antarctica (a proxy for the Southern Hemisphere westerly winds intensity) suggest a link between the southward displacements of the sSASG and the Southern Hemisphere westerly winds ${ }^{58}$. The southward (northward) displacement of the STF has commonly been correlated to the increased (reduced) water inflow from the Indian to the Atlantic Ocean through the Agulhas Leakage ${ }^{59,60}$. A SST record under the influence of the Agulhas Leakage indeed shows systematic millennial-scale increases during HS, indicating southward shifts of the STF (Fig. 3c) ${ }^{15}$. Also, a planktonic foraminiferal index for the relative position of the STF in 
the South Atlantic (\% Neogloboquadrina pachyderma (sinistral) / N. pachyderma total) corroborates the southward migrations of the STF during HS (Fig. 3d) ${ }^{14}$. The strong correlation between the $G$. truncatulinoides record from the SSASG, Agulhas Leakage SST and the STF index (Fig. 3b-d) suggest that the position of the SSASG was closely related to the Southern Hemisphere westerly winds and the STF. We suggest that the extratropical atmospheric circulation accompanied the southward displacement of the ITCZ and the nSASG during the HS6-4 and HS1, as indicated by model experiments ${ }^{43}$.

A southward-displaced extratropical atmospheric circulation during HS6-4 and HS1, shifted the SSASG polewards. Model simulations of a collapsed AMOC show a positive temperature anomaly (ca. $4^{\circ} \mathrm{C}$ ) at ca. $500 \mathrm{~m}$ water depth in the SASG ${ }^{47}$. Concurrently, in the Antarctic Circumpolar Current the increased eddy heat transport together with a southern position of the westerlies, allowed for more heat to reach high southern latitudes causing a retreat in Antarctic sea ice ${ }^{47}$. The increased SST around Antarctica ${ }^{61}$ resulted in a strengthening of the Southern Ocean deep-water upwelling (e.g., ${ }^{62}$ ). Increased upwelling around Antarctica, in turn, fostered $\mathrm{CO}_{2}$ release to the atmosphere ${ }^{62}$. A weakened dust-driven biological pump in the Southern Ocean also contributed to the rise in atmospheric $\mathrm{CO}_{2}$ during $\mathrm{HS}$ (e.g., ${ }^{63}$ ) (Fig. $3 \mathrm{~g}$ ).

Decreases in G. truncatulinoides abundance at the nSASG and the absence of major changes in the abundance of this species at the SSASG (Fig. 3a-b) suggest a meridional contraction of the SASG during HS3 and HS2. At the end of Marine Isotope Stage (MIS) 3 and during most of MIS2, the abundance of $G$. truncatulinoides at the SSASG ${ }^{24}$ shows nearly constant values between $2-4 \%$ (Fig. 3b). This is the period (i.e., ca. 30-19 ka) when full glacial boundary conditions were reached. This period encompasses HS3 and HS2, which were not related to southward shifts of the SSASG (Fig. 3b). We suggest that the full glacial boundary conditions hindered the SSASG to migrate southwards even under HS forcing. Under full glacial boundary conditions, the northward migration of the Polar and Subantarctic Fronts together with extensive sea-ice around Antarctica probably hampered southward displacements of the SSASG. The striking increase in sea-ice in the Atlantic and Indian sectors of the Southern Ocean under full glacial boundary conditions corroborates this suggestion (Fig. 3e) ${ }^{52,53}$. The long-term expansion of sea-ice equatorwards was fostered by low obliquity ${ }^{64}$ that reached minimum value at ca. 30 ka (Fig. $\left.3 f\right)^{54}$. Changes in sea-ice extent should be accompanied by changes in the oceanic Polar and Subantarctic Fronts (e.g., ${ }^{12,16,65,66}$ ). Records on millennial-scale temporal resolution of the Agulhas Leakage SST, the position of the STF and dust flux to the Southern Ocean (Fig. 3c-d) ${ }^{14,15,58}$ confirm the presence of full glacial boundary conditions during HS3 and HS2. Importantly, full glacial boundary conditions were associated to a significant northward displacement of the Southern Hemisphere westerly winds and a marked decrease in Southern Ocean deep-water upwelling, that hindered $\mathrm{CO}_{2}$ to be released from the Southern Ocean to the atmosphere, as recorded in ice-cores during the HS3 and HS2 (Fig. 3e-g) ${ }^{55}$.

In summary, enhanced poleward heat fluxes occurred during HS6-4 and HS1 and were favored by southward shifts of the SASG. Such meridional migrations of the SASG may have played a central role on oceanic carbon storage or release during the last glacial period on millennial timescales by controlling 
heat delivery to the Southern Ocean. Regarding the ongoing poleward displacement of the SASG ${ }^{5}$, our results suggest that an increase in heat transport to the Southern Ocean may strengthens deep-water upwelling and $\mathrm{CO} 2$ release to the atmosphere, constituting a positive feedback for global warming.

\section{Conclusion}

Our new G. truncatulinoides abundance record, together with previously published records, show that the SASG migrated southwards during most HS of the last glacial and deglacial periods (i.e., HS6-4 and HS1). These events were responsible for the transfer of substantial amounts of heat from the SASG to the Southern Ocean, ultimately strengthening deep-water upwelling and $\mathrm{CO}_{2}$ release to the atmosphere. On the other hand, the SASG contracted during the HS3 and HS2, resulting in decreased poleward heat transfer, decreased deep-water upwelling and decreased $\mathrm{CO}_{2}$ release to the atmosphere. The contraction was forced by full glacial boundary conditions, namely equatorwards advance in sea-ice, as well as in the position of the Polar and Subantarctic Fronts. We suggest that the poleward heat transfer from the SASG had a pivotal role on the carbon cycle on millennial timescales. Our results indicate that the ongoing poleward displacement of the SASG may drive oceanic $\mathrm{CO}_{2}$ release that will act as a positive feedback to global warming.

\section{Declarations}

\section{Acknowledgments}

Logistic and technical assistance was provided by the captain and crew of the R/V Meteor. New data shown herein will be archived in Pangaea (www.pangaea.de). T.M.L. Pinho acknowledges the financial support from FAPESP (grant 2019/10642-6). C.M. Chiessi acknowledges the financial support from FAPESP (grant 2018/15123-4), CAPES (grants 564/2015, 88887.156152/2017-00, 88881.161151/201701 and 88881.313535/2019-01), CNPq (grants 302607/2016-1 and 422255/2016-5) and the Alexander von Humboldt Foundation. R.C.P.-R acknowledges the financial support from the European Union's Horizon 2020 iAtlantic project (grant 818123). M.C. Campos acknowledges the financial support from FAPESP (grants 2016/10242-0 and 2019/25179-0).

\section{Author contributions}

T.M.L.P. and R.C.P.-R. designed the study. T.M.L.P. analyzed the planktonic foraminifera fauna. T.M.L.P., C.M.C. and R.C.P.-R. wrote the manuscript. All authors contributed to the interpretation of the data, as well as reviewing and editing the manuscript. C.M.C. performed supervision, project administration and funding acquisition.

\section{References}


1. Rui Xin Huang, \& Russell, S. Ventilation of the subtropical north Pacific. J. Phys. Oceanogr. 24, 25892605 (1994).

2. Munk, W. H. On the wind-driven ocean circulation. J. Meteorol. 7, 80-93 (1950).

3. Schmitz, W. J., \& McCartney, M. S. On the North Atlantic Circulation. Rev. Geophys. (1993).

4. Roemmich, D., Gilson, J., Sutton, P. \& Zilberman, N. Multidecadal change of the South Pacific Gyre circulation. J. Phys. Oceanogr. 46, 1871-1883 (2016).

5. Yang, H. et al. Poleward Shift of the Major Ocean Gyres Detected in a Warming Climate. Geophys. Res. Lett. 47, (2020).

6. Marcello, F., Wainer, I. \& Rodrigues, R. R. South Atlantic Subtropical Gyre Late Twentieth Century Changes. Journal of Geophysical Research: Oceans123, 5194-5209 (2018).

7. Wu, L. et al. Enhanced warming over the global subtropical western boundary currents. Nat. Clim. Chang. 2, 161-166 (2012).

8. Yang, H. et al. Journal of Geophysical Research: Oceans. J. Geophys. Res. Ocean. 121, 3010-3028 (2016).

9. Auad, G. \& Martos, P. Climate Variability of the Northern Argentinean Shelf Circulation: Impact on Engraulis Anchoita . Int. J. Ocean Clim. Syst. 3, 17-43 (2012).

10. Polovina, J. J., Howell, E. A. \& Abecassis, M. Ocean's least productive waters are expanding. Geophys. Res. Lett. 35, 2-6 (2008).

11. Irwin, A. J. \& Oliver, M. J. Are ocean deserts getting larger? Geophys. Res. Lett. 36, 1-5 (2009).

12. Bard, E. \& Rickaby, R. E. M. Migration of the subtropical front as a modulator of glacial climate. Nature 460, 380-383 (2009).

13. Barker, S. et al. Interhemispheric Atlantic seesaw response during the last deglaciation. Nature 457, 1097-1102 (2009).

14. Barker, S. \& Diz, P. Timing of the descent into the last lce Age determined by the bipolar seesaw. Paleoceanography 29, 489-507 (2014).

15. Dyez, K. A., Zahn, R. \& Hall, I. R. Multicentennial Agulhas leakage variability and links to North Atlantic climate during the past 80,000-years. Paleoceanography 29, 1238-1248 (2014).

16. Peeters, F. J. C. et al. Vigorous exchange between the Indian and Atlantic oceans at the end of the past five glacial periods. Nature 430, 661-665 (2004).

17. Chiessi, C. M., Ulrich, S., Mulitza, S., Pätzold, J. \& Wefer, G. Signature of the Brazil-Malvinas Confluence (Argentine Basin) in the isotopic composition of planktonic foraminifera from surface sediments. Mar. Micropaleontol. 64, 52-66 (2007).

18. Hemleben, C., Spindler, M., Breitinger, I. \& Deuser, W. G. Field and laboratory studies on the ontogeny and ecology of some globorotaliid species from the Sargasso Sea off Bermuda. J. Foraminifer. Res. 15, 254-272 (1985).

19. Mulitza, S., Dürkoop, A., Hale, W., Wefer, G., \& Niebler, H. S. Planktonic foraminifera as recorders of past surface-water stratification. Geology 25, 335-338 (1997). 
20. Schiebel, R. \& Hemleben, C. Modern planktic foraminifera. Paläontologische Zeitschrift 79, 135-148 (2005).

21. Lohmann, G. P., \& Schweitzer, P. N. Globorotalia truncatulinoides' Growth and chemistry as probes of the past thermocline: 1. Shell size. Paleoceanography 5, 55-75 (1990).

22. Kaiser, E. A., Caldwell, A. \& Billups, K. North Atlantic Upper-Ocean Hydrography During the MidPleistocene Transition Evidenced by Globorotalia truncatulinoides Coiling Ratios. Paleoceanogr. Paleoclimatology 34, 658-671 (2019).

23. Kucera, M., Rosell-Melé, A., Schneider, R., Waelbroeck, C. \& Weinelt, M. Multiproxy approach for the reconstruction of the glacial ocean surface (MARGO). Quat. Sci. Rev. 24, 813-819 (2005).

24. Gottschalk, J., Skinner, L. C. \& Waelbroeck, C. Contribution of seasonal sub-Antarctic surface water variability to millennial-scale changes in atmospheric $\mathrm{CO} 2$ over the last deglaciation and Marine Isotope Stage 3. Earth Planet. Sci. Lett. 411, 87-99 (2015).

25. Locarnini, R.A., A.V. Mishonov, O.K. Baranova, T.P. Boyer, M.M. Zweng, H.E. Garcia, J.R. Reagan, D. Seidov, K.W. Weathers, C.R. Paver, and I. V. S. (2019). World Ocean Atlas 2018 , Volume 1 : Temperature NOAA Atlas NESDIS 81 WORLD OCEAN ATLAS 2018 Volume 1 : Temperature National Oceanic and Atmospheric Administration. World Ocean Atlas 2018, Vol. 1 Temp. A. Mishonov, Tech. Ed. NOAA Atlas NESDIS 81, 52pp. 1, 52 (2019).

26. Stramma, L. \& England, M. On the water masses and mean circulation of the South Atlantic Ocean. Journal of Geophysical Research: Oceans104, 20863-20883 (1999).

27. Hüls, M., \& Zahn, R. Millennial-scale sea surface temperature variability in the western tropical North Atlantic from planktonic foraminiferal census counts. Paleoceanography 15, 659-678 (200AD).

28. Jaeschke, A., Rühlemann, C., Arz, H., Heil, G. \& Lohmann, G. Coupling of millennial-scale changes in sea surface temperature and precipitation off northeastern Brazil with high-latitude climate shifts during the last glacial period. Paleoceanography 22, 1-10 (2007).

29. Schlitzer, R. Ocean Data View, ODV 5.2. 1. (2020).

30. Bahr, A. et al. METEOR-Berichte: South American Hydrological Balance and Paleoceanography during the Late Pleistocene and Holocene (SAMBA) - Cruise No. M125. 96 (2016) doi:10.2312/cr.

31. Campos, M. C. et al. A new mechanism for millennial scale positive precipitation anomalies over tropical South America. Quat. Sci. Rev. 225, (2019).

32. Govin, A. et al. Terrigenous input off northern South America driven by changes in Amazonian climate and the North Brazil Current retroflection during the last $250 \mathrm{ka}$. Clim. Past 10, 843-862 (2014).

33. Blaauw, M. \& Christeny, J. A. Flexible paleoclimate age-depth models using an autoregressive gamma process. Bayesian Anal. 6, 457-474 (2011).

34. Langner, M. \& Mulitza, S. Technical note: PaleoDataView - A software toolbox for the collection, homogenization and visualization of marine proxy data. Clim. Past 15, 2067-2072 (2019). 
35. McManus, J. F., Francois, R., Gherardl, J. M., Kelgwin, L. \& Drown-Leger, S. Collapse and rapid resumption of Atlantic meridional circulation linked to deglacial climate changes. Nature 428, 834837 (2004).

36. Lippold, J. et al. Does sedimentary 231Pa/230Th from the Bermuda Rise monitor past Atlantic Meridional Overturning Circulation? Geophys. Res. Lett. 36, 1-6 (2009).

37. Henry, L. G. et al. North Atlantic ocean circulation and abrupt climate change during the last glaciation. Science (80-. ). 353, 470-474 (2016).

38. Campos, M. C. et al. Constraining Millennial-Scale Changes in Northern Component Water Ventilation in the Western Tropical South Atlantic. Paleoceanogr. Paleoclimatology 35, 1-32 (2020).

39. Mulitza, S. et al. Synchronous and proportional deglacial changes in Atlantic meridional overturning and northeast Brazilian precipitation. Paleoceanography 32, 622-633 (2017).

40. Marshall, J., Donohoe, A., Ferreira, D. \& McGee, D. The ocean's role in setting the mean position of the Inter-Tropical Convergence Zone. Clim. Dyn. 42, 1967-1979 (2014).

41. Chiessi, C. M. et al. Thermal evolution of the western South Atlantic and the adjacent continent during Termination 1. Clim. Past 11, 915-929 (2015).

42. Chiang, J. C. H. \& Friedman, A. R. Extratropical cooling, interhemispheric thermal gradients, and tropical climate change. Annu. Rev. Earth Planet. Sci. 40, 383-412 (2012).

43. McGee, D. et al. Hemispherically asymmetric trade wind changes as signatures of past ITCZ shifts. Quat. Sci. Rev. 180, 214-228 (2018).

44. Trenberth, K. E. \& Caron, J. M. Estimates of Meridional Atmosphere and Ocean Heat Transports. J. Clim. 14, 3433-3443 (2001).

45. Green, B. \& Marshall, J. Coupling of trade winds with ocean circulation damps itcz shifts. J. Clim. 30, 4395-4411 (2017).

46. Portilho-Ramos, R. C. et al. Coupling of equatorial Atlantic surface stratification to glacial shifts in the tropical rainbelt. Sci. Rep. 7, (2017).

47. Pedro, J. B. et al. Beyond the bipolar seesaw: Toward a process understanding of interhemispheric coupling. Quat. Sci. Rev. 192, 27-46 (2018).

48. Reißig, S., Nürnberg, D., Bahr, A., Poggemann, D. W. \& Hoffmann, J. Southward Displacement of the North Atlantic Subtropical Gyre Circulation System During North Atlantic Cold Spells. Paleoceanogr. Paleoclimatology 34, 866-885 (2019).

49. Chang, P. et al. Oceanic link between abrupt changes in the north Atlantic ocean and the African monsoon. Nat. Geosci. 1, 444-448 (2008).

50. Venancio, I. M. et al. Millennial- to Orbital-Scale Responses of Western Equatorial Atlantic Thermocline Depth to Changes in the Trade Wind System Since the Last Interglacial. Paleoceanogr. Paleoclimatology 33, 1490-1507 (2018).

51. Rodrigues, R. R., Rothstein, L. M. \& Wimbush, M. Seasonal variability of the South Equatorial Current bifurcation in the Atlantic Ocean: A numerical study. J. Phys. Oceanogr. 37, 16-30 (2007). 
52. Shemesh, A. et al. Sequence of events during the last deglaciation in Southern Ocean sediments and Antarctic ice cores. Paleoceanography 17, 8-1-8-7 (2002).

53. Crosta, X., Sturm, A., Armand, L. \& Pichon, J. J. Late Quaternary sea ice history in the Indian sector of the Southern Ocean as recorded by diatom assemblages. Mar. Micropaleontol. 50, 209-223 (2004).

54. Berger, A. \& Loutre, M. F. Insolation values for the climate of the last 10 million years. Quat. Sci. Rev. 10, 297-317 (1991).

55. Köhler, P., Nehrbass-Ahles, C., Schmitt, J., Stocker, T. F. \& Fischer, H. A 156 kyr smoothed history of the atmospheric greenhouse gases $\mathrm{CO} 2, \mathrm{CH} 4$, and $\mathrm{N} 2 \mathrm{O}$ and their radiative forcing. Earth Syst. Sci. Data 9 , 363-387 (2017).

56. Stramma, L. The South Indian Ocean Current. J. Phys. Oceanogr. 22, 421-430 (1992).

57. De Deckker, P., Moros, M., Perner, K. \& Jansen, E. Influence of the tropics and southern westerlies on glacial interhemispheric asymmetry. Nat. Geosci. 5, 266-269 (2012).

58. Lambert, F., Bigler, M., Steffensen, J. P., Hutterli, M. \& Fischer, H. Centennial mineral dust variability in high-resolution ice core data from Dome C, Antarctica. Clim. Past 8, 609-623 (2012).

59. Beal, L. M. et al. On the role of the Agulhas system in ocean circulation and climate. Nature $\mathbf{4 7 2}$ 429-436 (2011).

60. Biastoch, A., Böning, C. W., Schwarzkopf, F. U. \& Lutjeharms, J. R. E. Increase in Agulhas leakage due to poleward shift of Southern Hemisphere westerlies. Nature 462, 495-498 (2009).

61. Jouzel, J. et al. Orbital and millennial antarctic climate variability over the past 800,000 years. Science (80-. ). 317, 793-796 (2007).

62. Anderson, R. F. et al. Wind-driven upwelling in the southern ocean and the deglacial rise in atmospheric C02. Science (80-. ). 323, 1443-1448 (2009).

63. Jaccard, S. L., Galbraith, E. D., Martínez-Garciá, A. \& Anderson, R. F. Covariation of deep Southern Ocean oxygenation and atmospheric CO2 through the last ice age. Nature 530, 207-210 (2016).

64. Levy, R. H., Meyers, S. R., Naish, T. R., Golledge, N. R., McKay, R. M., Crampton, J. S., ... Kulhanek, D. K. Antarctic ice-sheet sensitivity to obliquity forcing enhanced through ocean connections. Nat. Geosci. 12, 132-137 (2019).

65. Groeneveld, J. \& Chiessi, C. M. Mg/Ca of Globorotalia inflata as a recorder of permanent thermocline temperatures in the South Atlantic. Paleoceanography 26, 1-12 (2011).

66. Howard, W. R., \& Prell, W. L. Late Quaternary Surface Circulation of the Southern Indian Ocean and its Relationship to Orbital Variations. Paleoceanography 7, 79-117 (1992).

67. Stainforth, R. M., Lamb, J. L., Luterbacher, H., Beard, J. H. \& Jeffords, R. M. Cenozoic Planktonic Foraminiferal Zonation and Characteristics of Index Formsle. Univ. Kansas Paleontol. Contrib. 62, 1425 (1975).

68. Hemleben, C., Spindler, M. \& Anderson, O. R. Modern Planktonic Foraminifera. (1989).

69. Volbers, A. N. A. \& Henrich, R. Calcium carbonate corrosiveness in the South Atlantic during the Last Glacial Maximum as inferred from changes in the preservation of Globigerina bulloides: A proxy to 


\section{Figures}
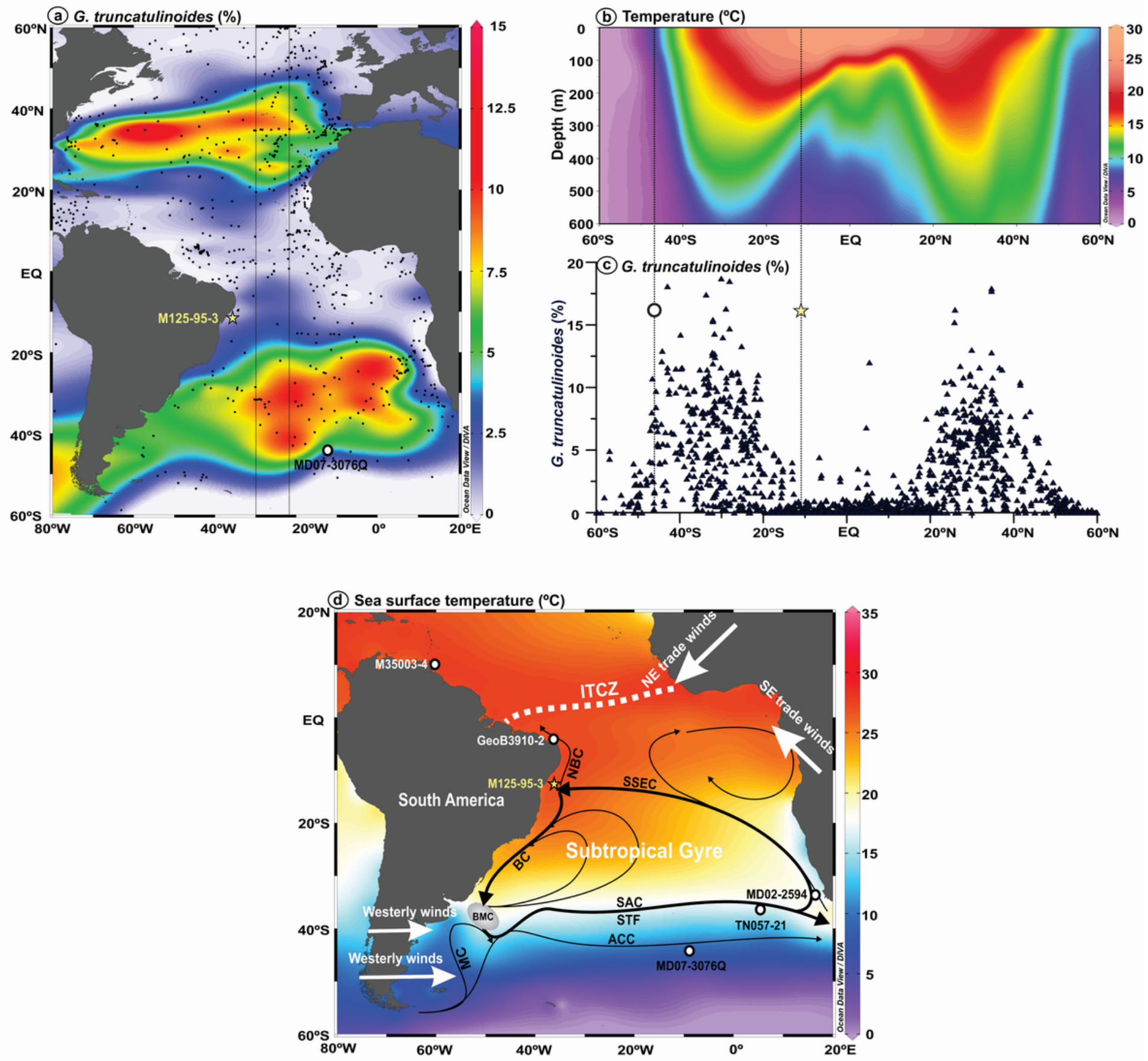

Figure 1

Location of marine sediment core M125-95-3 (yellow star) and other marine records discussed herein (open black dots). (a) Map of the modern relative abundance of planktonic foraminifera species Globorotalia truncatulinoides in the Atlantic Ocean23. Black dots represent the location of the surface sediment samples. The thin rectangle indicates the location of the temperature meridional profile 
depicted in panel "b". (b) Mean annual temperature meridional profile for the upper $600 \mathrm{~m}$ of the water column of the Atlantic Ocean25. Vertical dotted lines delimit the South Atlantic Subtropical Gyre (SASG) See panel "a" for the location of the meridional profile. (c) Meridional profile of the modern relative abundance of $\mathrm{G}$. truncatulinoides in the Atlantic Ocean23. The yellow star depicts the location of core M125-95-3 (this study) and the open black dot depicts the location of core MD07-3076Q24. (d) Mean annual sea surface temperature (color shading) 25, schematic surface ocean circulation (black arrows) 26 and atmospheric features (white arrows) of interest over the South Atlantic. Antarctic Circumpolar Current (ACC), Brazil Current (BC), Brazil-Malvinas Confluence (BMC), Intertropical Convergence Zone (ITCZ), Malvinas Current (MC), North Brazil Current (NBC), South Atlantic Current (SAC), Southern South Equatorial Current (SSEC), Subtropical Front (STF). The location of the following cores are depicted: M35003-427, GeoB3910-228, M125-95-3 (this study), MD02-259415, TN057-2114, MD07-3076Q24. This figure was partially produced using the Ocean Data View (ODV)29. 


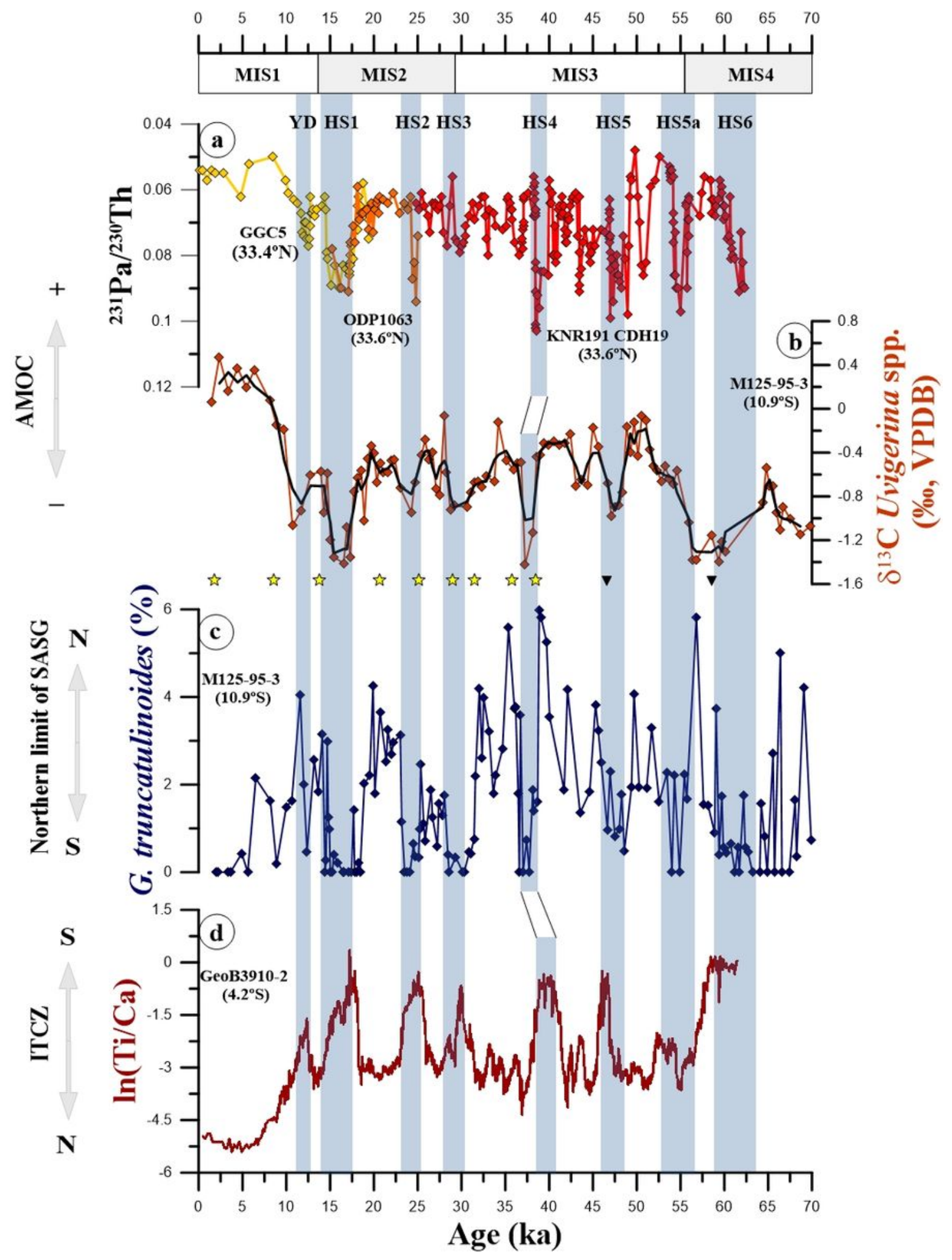

Figure 2

Comparison of relative abundance record of Globorotalia truncatulinoides from marine sediment core M125-95-3 with previously published records from the Atlantic Ocean. (a) 231Pa/230Th from the Bermuda Rise35-37. (b) Uvigerina spp. stable carbon isotopic composition ( $813 \mathrm{C}$ ) from core M125-95-3 (running average of 3 points)38. (c) Relative abundance of G. truncatulinoides from core M125-95-3 (this study). (d) In(Ti/Ca) from core GeoB3910-228. Yellow stars on top of panel "c" depict calibrated 
radiocarbon ages and black triangles depict tie-points used to produce the age model of core M125-95-3 ( $2 \sigma$ standard error smaller than symbol size)31. Blue vertical bars represent millennial-scale Heinrich Stadials (HS) 6-1 and the Younger Dryas (YD). Marine Isotope Stages (MIS) are depicted below the upper horizontal axis. Atlantic Meridional Overturning Circulation (AMOC), South Atlantic Subtropical Gyre (SASG), Intertropical Convergence Zone (ITCZ).

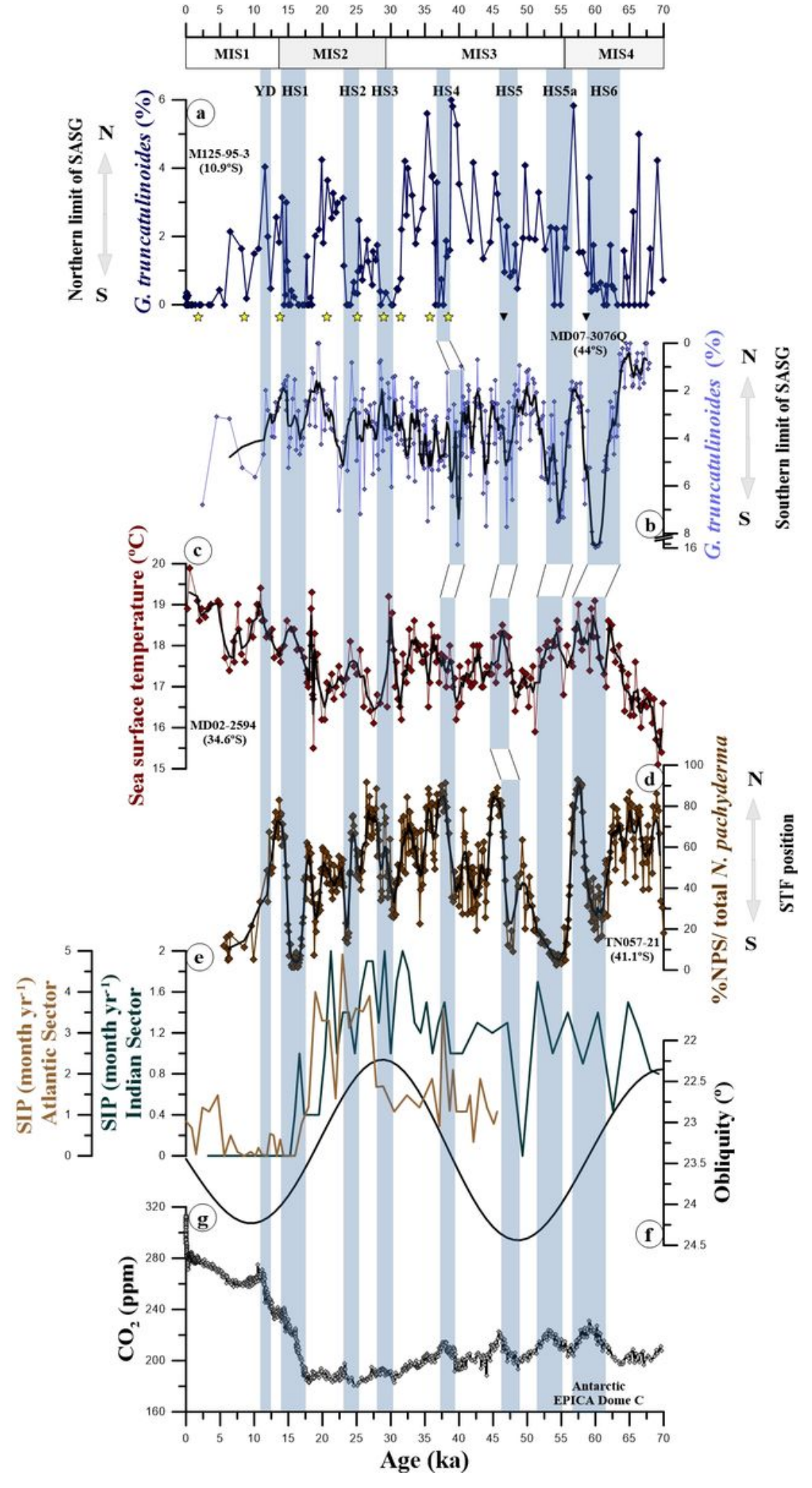

Figure 3 
Relative abundance of Globorotalia truncatulinoides from cores M125-95-3 (this study) and MD073076Q24 located at the northern and southern limits of the South Atlantic Subtropical Gyre (i.e., nSASG and SSASG), respectively together with other proxy records discussed herein. (a) Relative abundance of G. truncatulinoides from core M125-95-3 (this study). (b) Relative abundance of G. truncatulinoides from core MD07-3076Q (running average of 5 points) (note the inverted axis)24. (c) Mg/Ca-based sea surface temperatures in the Agulhas Leakage (running average of 3 points)15. (d) Ratio of the percentage of Neogloboquadrina pachyderma (sinistral; NPS) to total N. pachyderma (sinistral and dextral) from core TN057-21 (running average of 7 points)14. (e) Southern Ocean sea-ice presence (SIP) in the Atlantic and Indian sectors of the Southern Ocean52,53. (f) Obliquity54. (g) Atmospheric CO2 concentration55. Yellow stars on top of panel "b" depict calibrated radiocarbon ages and black triangles depict tie-points used to produce the age model of core M125-95-3 (2 $\sigma$ standard error smaller than symbol size)31. Blue vertical bars represent millennial-scale Heinrich Stadial (HS) 6 to 1 and the Younger Dryas (YD). Marine Isotope Stages (MIS) are depicted below the upper horizontal axis. Subtropical front (STF).

\section{Supplementary Files}

This is a list of supplementary files associated with this preprint. Click to download.

- Supplementarylnformation.pdf 